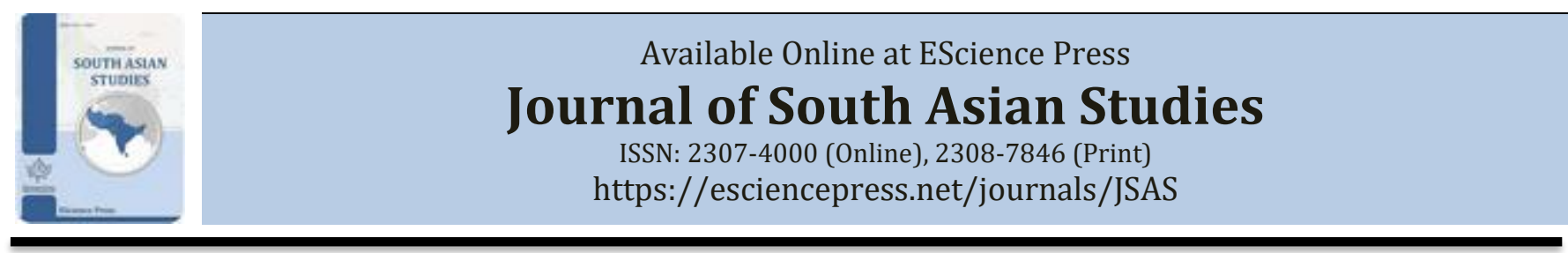

\title{
AMBIGUITY AS DISCURSIVE STRATEGY: A CRITICAL ANALYSIS OF PAKISTANI POLITICAL LEAGUE'S SELECTED DISCOURSE REGARDING COVID-19
}

\author{
Muhammad A. Khan, Sumra M.J. Satti \\ Department of English, The University of Lahore, Gujrat Campus.
}

*Corresponding Author Email ID: sumraashfaq610@gmail.com

\begin{abstract}
A B S T R A C T
This study unearths the ambiguities found in the discourse of prominent Pakistani political league during the outbreak of the pandemic covid-19 from the perspective of critical discourse analysis (CDA). CDA is an approach to the analysis of discourse which considers language as a social practice and takes particular interest in the ways in which ideologies and power relations are expressed through language (Fairclough, 2015). This paper presents a reflection to unveil the discursive strategies which are being used by the major Pakistani political parties' leaders as they did not come up with any plan of action pertaining to covid-19 yet. These statements are merely based on criticism only for the sake of criticism without any systematic planning and logical way out to get rid of this critical situation. This analysis is guided by the framework of Fairclough's model of CDA (2015) which consists of three inter-related processes of analysis tied to three inter-related dimensions of discourse. This paper highlights the ideological perspective of Prime minister Imran Khan, opposition leaders i.e., PML-N leader Shahbaz Shareef, Chairman Pakistan People's Party, Bilawal Bhutto Zardari and Molana Fazal-u-Rehman. This study found out that the statements which are given by the major political parties on different political forums are full of vague ideas and uncertainty about Corona virus outbreak which is, in a way, evidence regarding their failure to understand and tackle the dire situation.
\end{abstract}

Keywords: Discursive strategy, Ambiguity, Critical discourse analysis, Pakistani political league, Covid-19.

\section{INTRODUCTION}

Language is considered as the most powerful tool as it makes or breaks relations in the world. There are numerous definitions of language which are proposed by many renowned people. According to Encyclopedia Britannica (1768), Language, a system of conventional spoken, manual (signed), or written symbols by means of which human beings, as members of a social group and participants in its culture, express themselves. The functions of language include communication, the expression of identity, play, imaginative expression, and emotional release.

When we move forward towards language use or discourse, there are important connections among saying (informing), doing (action) and being (identity). If something is said to anyone, it cannot be understood fully until one is not aware of what a person is trying to say (intention) and who is the person addressing (Identity). This concept is given by Gee (2011) who considers language as combination of saying, doing and being.

Discourse analysis is the study of language-in-use. There are many different approaches to discourse analysis in general. Some of the approaches are called "descriptive" and their goal is to describe how language works in order to understand it. Quite the reverse, other approaches are termed as critical i.e. "Critical discourse analysis" which answer the questions differently. Their goal is not merely to describe how language works or even to offer deep explanations, but they intervene in social and political issues, problems and conflicts in the world. They intend to put forward their work to the world in some fashion (Gee, 2011).

From the perspective of Gee (2001), discourse analysis needs to be critical not because discourse analysts are or need to be political but because language is inherently political. It can be elucidated from his point of view that when something is said, there is always some intention behind it. In other words, some hidden motif prevails in 
words, resultantly, language is considered as keyway for humans to make or break the world. Therefore, Discourse analysis can highlight issues and controversies in the world. Discourse is socially constitutive as well as socially conditioned- it constitutes situations, objects of knowledge, and the social identities of and relationships between people and groups of people. It is constitutive both in the sense that it helps to sustain and reproduce the social status, and in the sense that it contributes to transforming it. Since discourse is so consequential, it gives rise to important issues of power, inequality, domination etc. (Fairclough \& Wodak, 1997). Resultantly, discourse becomes a tool in the hands of the powerful to attain their goals. When we encounter the term, "Critical, it connotes change and CDA views language as a social practice and this approach takes great interest in the ways that ideologies and power relations are expressed through language. The analysts are specifically interested in issues of inequality and injustice existing in society. Critical discourse analysis (CDA) stems from a critical theory of language which sees the use of language as a form of social practice (Janks, 1997).

This research demonstrates at looking how political parties use various linguistic tools to manipulate the stereotypical ideology of showing a great concern towards health issues of the public in order to build a positive image through media and how people of Pakistan are being manipulated by this ideology.

CDA takes a particular interest in the relationship between language and power as they have more ideological effects on the audience. The practical linking of "social and political engagement" with a sociologically informed construction of society (Krings et al.,1973). The language used by the political leaders is full of persuasion which tempts public to construct positive image of their respective parties. It is the manifestation of relation between language and power. As political leaders are fully aware of the power of words which can create situation and help them to produce and reproduce their image in front of the public while using discursive strategies. Fairclough (1995) explained and elaborated some advances in showing not only how the analytical framework for investigating language in relation to power and ideology developed, but also how CDA is useful in disclosing the discursive nature of much contemporary social and cultural change.

CDA takes a particular interest in the ways in which language mediates ideology in a variety of social institutions (Wodak, 2001). There are always certain reasons behind the concept of planning something resulting in an action. Moreover, the study of ideology has to bear in mind the variety of theories and theorists that have examined the relation between thought and social reality. All the theories assume that there are specific historical reasons why people come to feel, reason, desire and imagine as they do (Eagleton, 1994).

Fairclough's model (1989) is useful in this study as it enables readers to focus on the particular linguistic selections, their ordering, lay out and so on. It helps them to recognize the historical determination of these selections and to understand that these choices are tied to the conditions of the possibility of that utterance. Texts are instantiations of socially regulated discourses, production and reception processes are socially constrained. In this model, three dimensions are interconnected and as an analyst I can work on interesting patterns that need to be described, interpreted and explained.

\section{THEORETICAL FRAMEWORK AND METHODOLOGY}

Orientational research has been conducted in this study as CDA is based on this research which further stands on critical theory. A Critical theory is a collection of different theories, and it identifies elements of inequality and injustice which exists and they should be eradicated from society.

For Linguistic analysis of selected political speeches, Fairclough's (1989) Three-Dimensional Model (TODA) has been employed. Speeches can be considered as media discourse because these are delivered through media on political forums as these involve language and social practices. These three dimensions are

1. The object of analysis (political speeches of PM and Opposition)

2. The processes by means of which the object is produced and reviewed (Viewing/Listening)

3. The socio-historical conditions which govern these processes.

According to Fairclough (1989), each of these dimensions require a different kind of analysis

1. Text Analysis (Description)

2. Processing analysis (Interpretation)

3. Social analysis (Explanation)

This model emphasizes on the interdependence of these dimensions and the intricate moving back and forth between the different types of analysis which this 
interdependence requires. (Janks, 1997)

\section{AIMS AND OBJECTIVES}

1. to show the hidden aims and purpose of political parties

2. to unveil their failure to provide strategic planning regarding covid-19

3. to demonstrate impact of discursive strategies used by political leaders.

\section{RESEARCH QUESTIONS}

1. How do Pakistani political leaders employ ambiguity as discursive strategy in their selected discourses regarding covid-19?

2. How do political figures state opposing conflicts for each other's results in uncertainty pertaining to Covid-19?
TOOL

The ambiguity pertaining to covid-19 which surrounds the whole country is noticed through Observation from speeches of political leaders on different news channels.

\section{Fairclough's (2015) three-dimensional Model (Description, Interpretation and Explanation)}

This first stage of Fairclough's (1989) model is Description which involves textual analysis of the discourse used in the speeches delivered by major political parties of Pakistan. The frame of interest here is to describe their perspective as it is in this stage. The linguistic features include adjectives, imperative sentences and persuasive conversation. The lexical items are the main source to describe one's standpoint. They are the most effective and powerful weapon to persuade the public with promising intention. It is to create a specific ideology behind their words.

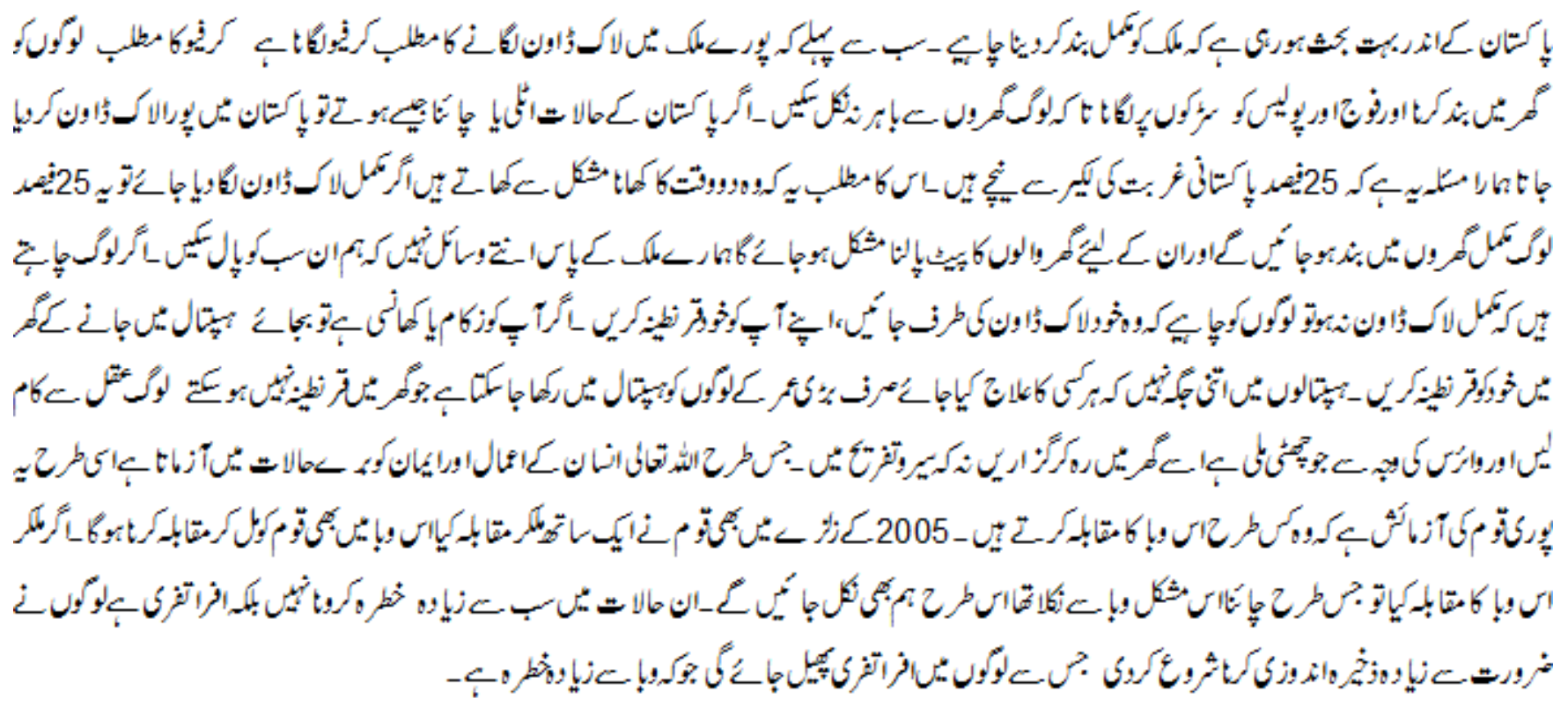

\section{PM IMRAN KHAN'S PERSPECTIVE ABOUT COVID-19}

PM Imran Khan (March 22, 2020) addressed the nation on Corona virus outbreak and stated that there is a lot of argumentation on the unsettled issue of lockdown during Covid-19. He has emphasized on the comparison of our country with the rest of the countries and declared that same solution does not seem appropriate due to entirely different economic conditions and affordability. Furthermore, he highlighted the limited resources which make us unable to supply food items to $25 \%$ of the people who are suffering from poverty. He has shown his concern towards people who are on daily wages, taxi drivers etc. He emphasized that he is unable to announce lockdown due to bad financial conditions of the country. Quite the reverse, he said that there is no need to panic as we have a lot of food resources to supply to the needy people in this critical situation. He has given his stance that people have to keep trust in him as the situation can be worst with hustle bustle in the country. He further stated that Corona is nothing more than influenza so instead of getting perplexed, people should discipline themselves and get self-quarantine. There is no need to go to hospital as old or aged people need it the most. Moreover, he stressed that lockdown means keeping people at their homes through enforcement by police and Army. 
However, PM requested the nation for self-quarantine as our country is not in a position for lockdown, so everyone has to play a significant role to safe country from spreading the curb of virus.

The PM on March 24, 2020, addressed the nation and said that corona is not dangerous but the spread of confusion pertaining to corona is more dangerous. The impression of lockdown is spreading uncertainty as we are more inclined towards aftereffects. The fear of taking inappropriate decisions which can turn into trivial results is creating dreadful situations for the Government. He stated in National Security Council (2020) that when 21 cases were reported, lockdown had already been started which meant the closure of schools, shopping malls, marriage halls and public places. He mentioned that we are concentrating on English medium schools and our focus is not on Urdu medium schools and religious institutions. However, he started asking questions from the public that," Are we in a position to have a total lockdown?" How can we provide food items to the needy people?" "What would be the overall impact on the society?"

PM Imran Khan on May 28, 2020, spoke to the World's Economic Forum's Covid Action Platform to underline the dilemma faced by the developing economies due to coronavirus outbreak. For many countries, a lockdown means taking risk for the starvation of the poorest and so they may encounter the public health threat and keep their economies functional but global cooperation debt relief can help countries like Pakistan better resource their health systems. The World's Economic forum is the international organization for the Public-private cooperation. The Forum engages the foremost political, business, cultural and other leaders of the society to shape global, regional and industry agendas. $\mathrm{He}$ addressed the nation and said that government has arranged stimulus package, but this program is unaffordable in long-term. Besides this, corona cases are increasing on daily basis, we have to open our construction companies, business sectors as we are not in a position to close them for long run. He has emphasized on the cooperation that the world must cooperate to avoid the economic destruction of the coronavirus pandemic.

Furthermore, Prime Minister Imran Khan on October 4, 2020 cautioned that a second wave of the novel coronavirus may hit cities with a high level of pollution in the coming months as the winter season approaches. He further said that government had imposed a lockdown to curb the spread of Covid-19 when the country had only 26 cases and no deaths. He added, the provinces overreacted and projected themselves unnecessarily because lockdown had become a worldwide phenomenon and the country did not have centralized planning at that time. The second stage of Fairclough's model (2015) deals with interpretation of the discourse used in the speeches and conferences conducted by the Pakistani political league. It focuses on processing analysis (Analyzing the process of production and reception).

Fairclough $(1989,2015)$ refers to the situational context and the inter-textual context as central to the process of interpretation. As far as interpretation is concerned, few questions arise here.

- How will political parties settle the issue of lockdown in collaboration with each other?

- Will political figures come up with any strategic planning to get rid of this virus?

We commence with PM's first speech which was delivered on March 22,2020 in which he has shared his view that complete lockdown is not a solution as we cannot afford it lockdown is not possible due to poverty crisis which constitutes of $25 \%$ people in our country. He has talked about limited resources and the problems which we are encountering at the moment. Conversely, he stated that we have a lot of food resources, and it is manageable to supply food items to the poor people in the same speech. In my perspective, these constantly changing statements by PM created hype and vagueness among masses as public relies on the PM of the country. Despite all the severity of Covid, he said it is not lethal, but hustle bustle or mess can make it contagious as he called it same like influenza or flu. To interpret his thoughts, I would say he is creating such an environment that people should take it easy because this virus is not going to engulf them. This thought was just opposite to reality which introduced fearful situation for the public. As PM said that people should not run to hospitals because of usual symptoms of flu as old people require to be treated in hospitals because of low immunity. These statements can be quite discouraging for the people who became victim of this contagious virus as old people were not the only ones who were dying from the lethal virus rather young people were losing their lives too. There is no sound directive provided by the government. With these vague statements of PM, it can be assessed that he wants to make public aware of the limited resources of the 
country i-e lack of spaces in hospitals, ventilators, equipment required to deal with corona patients etc. He started asking questions from the public about our financial conditions and limited resources etc. First of all, he made it clear that we cannot afford lockdown because of our financial conditions. Secondly, he mentioned lockdown had already started and so on. He keeps on talking about lockdown sometimes in favor sometimes in disfavor which is a true reflection of vagueness in his mind about uncertain decisions. He has portrayed the image of helplessness which caused doubts among public that if people could have suffered from this disease, they would have to die as no one knows the solution and because of limited resources. Similarly, he has floated the idea of self-quarantine that those people should quarantine themselves who feel the symptoms of flu etc. what if those $25 \%$ people suffer from those symptoms, self-quarantine will not be the solution for them as they have to earn bread and butter on daily basis. Who will provide them food if they quarantine themselves?

Likewise, PM has announced (March22, 2020) that we are not in such a situation to take stand for complete lockdown and the very next day, lockdown has started everywhere. This situation was contrary to the statement which PM gave the previous day. He said so that we cannot do reinforcement for lockdown by police, but we have seen that police were standing everywhere and forcing people to stay at home.

There was a contradiction in words and action by PM.
What was told to the public contradicted to the plan of action all of a sudden? It created a huge communication gap between public and government.

All the questions of serving 25\% (needy) people remained unanswered. From his standpoint, construction industries and business sectors should be functional to meet our needs in spite of increasing corona cases. In my stance, if it is the case, PM should have taken the same decision before which he has taken one month later as we cannot survive with the limited resources so he should have worked it out without tangling the uncertain decisions of keeping or withdrawing lockdown as it has just created the air of uncertainty. He mentioned that he was more focused towards aftereffects of any decision but he kept on taking decisions which were not constant and conflicts prevail between words and actions. It was merely uncertain condition for all the country when no one knows where this situation is taking us or are we going to survive in this critical time? He defended his government's response to the coronavirus crisis, saying there has been no confusion or contradiction in official policies since the start of the pandemic. To interpret defensive approach of PM, Self-righteous approach can be noticed where he prefers to prove that wise decisions are taken with mutual agreement according to current scenario. Unfortunately, public could not get right direction from the government to fight back against roaring pandemic.

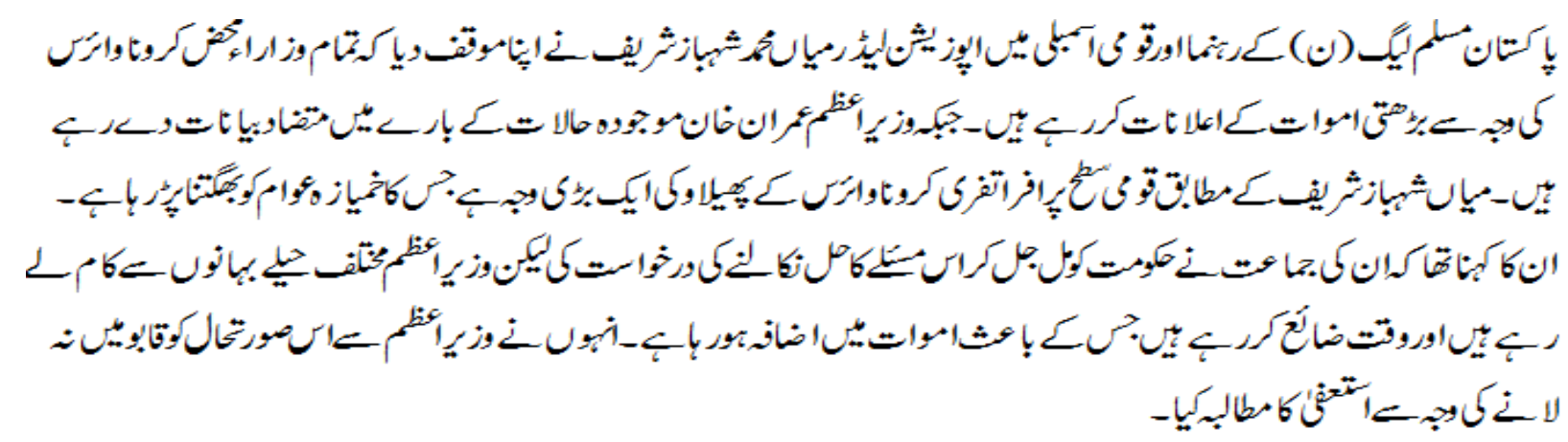

\section{PML-N LEADER SHABAZ SHAREEF'S VIEW REGARDING COVID-19}

The leader and president of PML-N Mr. Shahbaz Shareef (June 23,2020) has given his standpoint that all ministers are announcing rising mortality rates due to covid-19 and PM Imran khan is giving conflicting speeches about current situation. He stated that this confusion at National level is the major cause of spreading coronavirus and public is paying for it. Similarly, he mentioned that his party has requested government for collaborative strategic planning as there is huge increase in coronavirus patients, but PM is making lame excuses every day. He further elaborated that PM is wasting time and he is not doing anything practical. Consequently, people are dying day by day. He has demanded resignation from PM because of his failure in managing 
with this pandemic issue.

The PML-N leader Shahbaz Shareef kept on criticizing government for the perplexed situation as he claimed that his party has requested government for collaborative efforts, but it could not get any satisfactory response. Consequently, mortality rate is at its peak so PM should leave the seat as he is unable to cope with this situation. He repeatedly mentioned the contradictory statements which create uncertainty for public by PM as portrayed that this government is not eligible to handle such sort of situations and people are dying due to their incompetence.

To interpret his thoughts, he demanded seat only on behalf of his party. Throughout his statements, he did not give a single solution that how to overcome this virus and what should be the systematic planning by government? He did not mention where government is committing mistakes rather, he contradicts with the announcements made by the government.

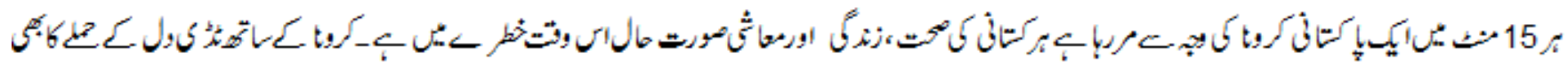

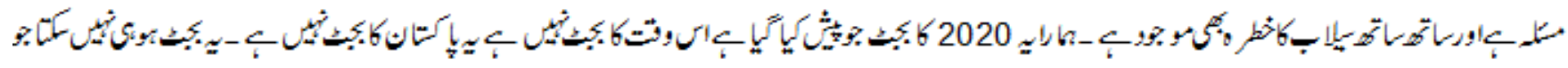

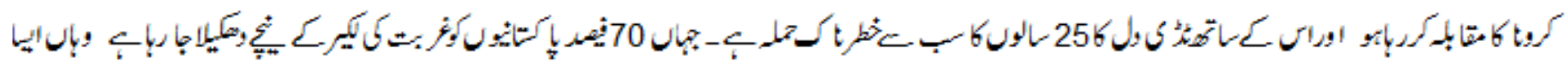

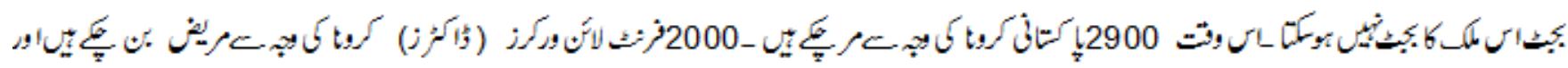

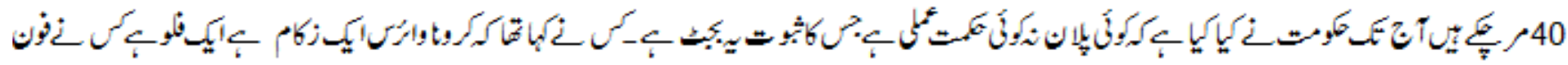

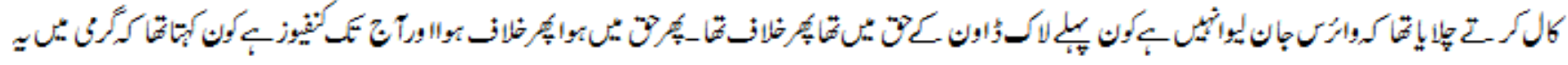

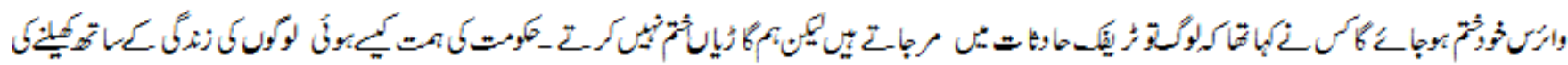

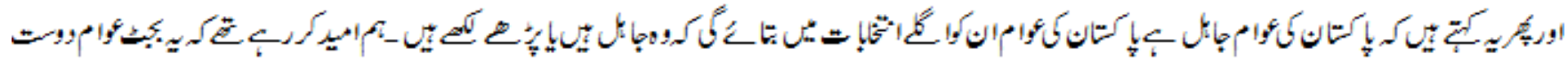

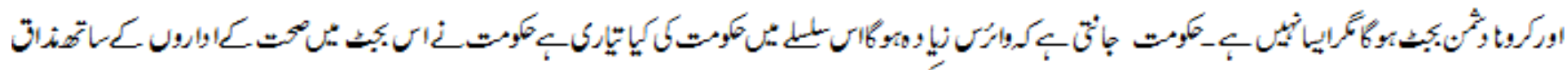

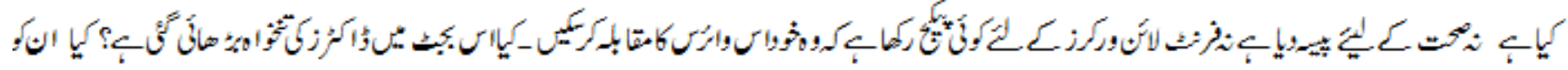

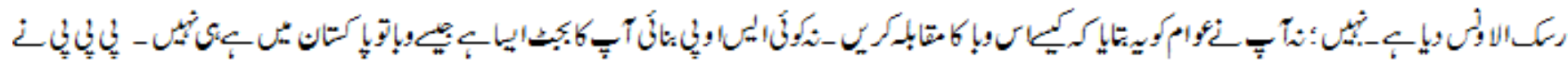

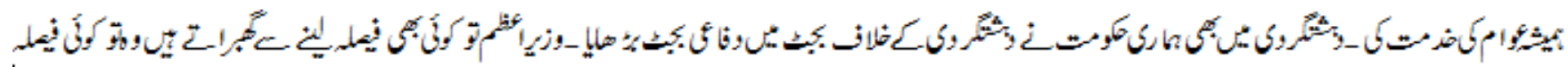

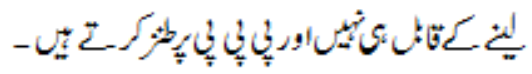

\section{THE CHAIRMAN OF PPP BILAWAL BHUTTOS' OPINION ABOUT COVID-19}

While responding to a journalist in press conference, the Chairman PPP Bilawal Bhutto (May 1,2020 ) said that his party introduced Corona, first in China (Wuhan), Italy, Iran and now in Pakistan. PPP is not the conspirator rather it is PTA itself. He said that his party (PPP) did not make corona. He revealed that his party's focus is not on politics rather PPP is focusing on Coronavirus outbreak at the moment. In this trivial situation, doctors and nurses are losing their lives and putting their families at risk, there are predictions of flood, global recession and economic depression in Pakistan, PPP focuses on saving precious lives and improving health facilities rather than contributing in politics.

On June 16,2020 , he gave his opinion in National assembly that coronavirus has expanded everywhere because of illogical policies of government as causalities are being recorded after every 15 minutes due to corona. He has raised issue of budget that it cannot be the budget of Pakistan which is presented in 2020. It is budget of some other country or some other place as it is not a pandemic budget. There is no increase in salaries of doctors and paramedical staff and no amount is defined for hospitalization. He has criticized government by saying that 2000 doctors and nurses became victim of Covid due to inappropriate policies by government. He has repented that a lot of people are suffering from the lethal virus and Federal government does not have any strategic planning to handle this situation. He asked a question from government that what government did for our front-line workers so far. It is merely depiction of government's 
confusion, incompetence, negligence, no direction, no plan, and no strategy which the decided budget reflects upon. He further mentioned that Who said so that corona is just influenza and flu, it is not lethal or contagious (recorded telephonic message), it would end in summers etc. Moreover, he said that government is confused as PM Imran khan goes in favor of lockdown then disfavors and keep on giving ambiguous statements which lack clarity. The Chairman PPP quoted the example given by PM that if we have more accidents, we cannot stop transport or traffic. He has criticized Federal government for spreading Covid forcefully. He mentioned that PM is afraid of taking decisions and how dares he blamed Pakistani people for being cause of spreading virus. He stated that it is the incompetence and failure of PM Imran khan to sort out the situation amicably. He said that originality of PM is shown at the time of crisis as he is not briefing public for awareness of Covid-19. Being Leader of the house, he should have been present in the house for National unity so that all the parties could have worked out in creating awareness regarding Covid. He declared in the press conference that difference of opinion should not be given space at the time pandemic, but government did not give satisfactory response rather reacted against Sindh government that Sindhi people are illiterate that's why corona has spread there. He said that public would respond in upcoming elections as it is being victimized.

The chairman PPP Bilawal Bhutto criticized on the policies made by the government, and he blamed government for this pandemic. To analyze his perspective, one can clearly see that he just said that government does have any solution for our current situation when doctors, nurses and paramedical staff are suffering and dying because of the lethal virus. He himself remained equally unsuccessful for some systematic and organized planning to fight back against coronavirus. He raised issue of budget in the same speech which was irrelevant as country is passing through crisis of chronic disease. He indirectly quoted the statements of PM Imran khan that he said so it is not lethal, it will end up in summers, it is just influenza, but reality is opposite to the said statements. The Chairman PPP condemns the incompetence and failure of government for not fulfilling the promise of taking care of the public and their health issues. He kept on quoting PM'S words that he is unable to take protective steps for the people of Pakistan. He said that PM should not only be PM of PTI rather he should be PM of Pakistan. To evaluate his perspective, he kept on criticizing on Federal government for its failure to tackle the situation. On the contrary, he did not propose any single idea to overcome this pandemic. He said that PPP warns government about upcoming dangers always, but government remain defensive by targeting Sindh Government. In my view, if PPP is already informed and updated about upcoming hazards so why it is not coming up with some organized planning and strategies free from domestic politics. He mentioned that testing capacities have increased in Pakistan and the credit goes to Sindh government. From the perspective of analysis, "why the chairman PPP talks about credit"? The hidden underlying purpose is to depict positive image of PPP rather than doing something for the benefit of people against coronavirus outbreak. I would prefer to use the term "Pseudo positivity" for this kind of attitude. To illustrate pseudo positivity, I would say self-projection in a positive way to catch the attention of common masses. He said that public will respond in Elections. This statement clearly shows that he intends to take the benefit of crucial time by manipulating the interest of public from PTI to PPP as political motif is at its peak in the background which analyst can easily coin by going into the depth of meaning. This is the core of CDA to determine the underlying meaning through ideology. There is no significant contribution of PPP by working in collaboration with other major political parties to give some good ideas in subsiding health issues. Though he mentioned that PM Imran khan is confused about keeping or withdrawing lockdown, but he also did not state anywhere should it be kept or lifted up? Bilawal Bhutto is of the view that he belongs to different universe of discourse as compared to PM Imran khan as point of conflicts should not be given importance at the time of pandemic, but his actions and words confront his own statements. Another political figure (The Chairman, PPP) with vague statements creates doubts in the mind of people as they cannot be decisive that who is going in the right direction? This kind of politics at the time of crisis added more in uncertainty.

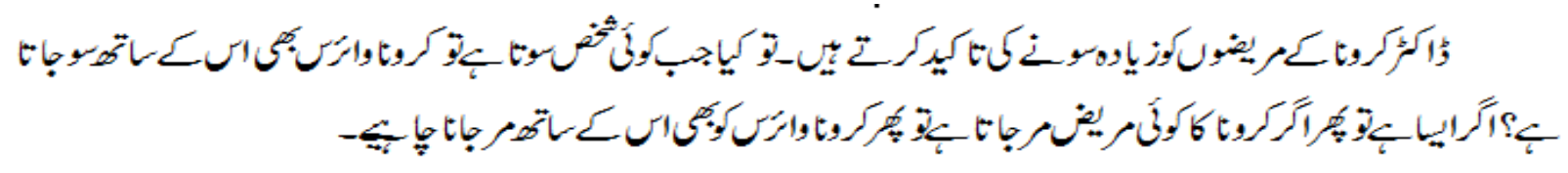


JAMEET ULMAY E ISLAM LEADER MOLANA FAZALUR REHMAN'S PERSPECTIVE PERTAINING TO COVID-19

MolanaFazal Ur Rehman (June 10, 2020) has given his point of view in conference that if it is the case that people sleep more, coronavirus will sleep more too. He has criticized on the idea that it cannot be spread through dead people who were victims of covid as it dies with the people. He refuted this idea completely.

Molana Fazalur Rehman has given a strange logic that people should sleep more if they want virus to sleep and not affect them. He criticized government against social distancing and avoiding funerals of people who became victim of covid. He negated the ideas of government rather his statements were not logical in anyway.

The specific linguistic selections by major political parties clearly interpret that uncertainty is prevailing everywhere. There is no plan of action from any of the political figure and they keep on criticizing each other for the sake of no-good reason. They just introduce discourse of good will to construct their positive image which can help them for Elections only.

They are using discursive practices to avoid questions from the public; they manipulate the ideology of people by throwing arrows towards each other. In reality, we cannot see any systematic strategy from Pakistani political league so far.

The third stage of Fairclough's model (1989) called Explanation evaluates the influence of these political statements on society. This level examines the impact of discourse on society (Social analysis) and influence of societal trends on the text. Critical discourse analysis considers language as social practice; it assumes that it can't function separately, but within social and cultural setting. The text is oral in this study as the political speeches are being analyzed. However, social factors play a major role in creating hype about the situation. The behavior noticed from the political parties during pandemic was not convincing and there were psychological implications of the given statements because an image was created with power of words that our political leaders seem helpless in controlling, monitoring, reducing the viral infection. Consequently, the wave of uncertainty is spreading about the lethal infection where people got scared and it affected their emotional health as well.

It can be evaluated that lack of clarity about near future and considerable measures by political leaders pertaining to Covid influenced society as a whole.
Pakistan is passing through a situation which was highly unpredictable for all sects of society i-e medical, education, law etc. In this pandemic, when the mortality ratio is at the peak and vaccination is not accessible to everyone, people are highly depressed and unaware of getting themselves safe from this lethal virus. They are not provided with any plan of action by the political sectors rather they are engaged in their own planning of getting political benefits.

Unfortunately, Criticism only for the sake of criticism is being followed by the political league as their concern is just to be good politicians rather than being good people who work for the welfare of others. Volunteers are not seen from any of the party who have put politics aside and did work to provide facilities to the needy people.

A number of speeches by prominent major political parties can be found on internet regarding Covid and we can only smell politics from them. It is not about precautionary measures only rather some effective strategy is required to get rid of this problem and take people out from the perplexed situation.

Undoubtedly, no one was ready for the disaster created by this cruel virus which has engulfed many precious lives but political leaders should have been worked together for some effective strategies and planning rather than taking advantage of situation and doing politics at the cost of depressing situation sustaining in the country.

Ideology is at its most powerful when it is invisible, when discourses have been naturalized and become part of our everyday common sense. The conditions of text production and text reception are gradually transformed (Janks, 1997).

The strength of CDA is that the different dimensions of analysis that it offers, provide the means both for producing research questions and for analysis them too.

Hence, it is ideologies prevailed in the society which is affecting majority of the people and influence them to be in quite a challenging state where they have to decide between real and unreal. In a nutshell, Vagueness dominated vividness which created ambiguity and it is used as discursive strategy by the major political parties of the country.

\section{CONCLUSION}

This study focuses on the linguistic analysis as well as the impact of political speeches on society and describes how political leaders remained unsuccessful for devising some useful strategies. Consequently, it leaves a strong impact 
on the Pakistani people that no one is certain about upcoming situation as vaccination, or any other alternative is not accessible so far. In addition, the threat of fourth layer of Covid is whirling around these days though we could not get rid of its third layer yet. It is predicted that Covid cannot be eliminated from the country as it is viral and either people have to adjust with it or they need to be vaccinated completely. First of all, those people who became victim of covid developed reactive anti-bodies against it. Secondly, medical specialists and pathologists are working on it so that vaccination can be made available to everyone which can cure people from this chronic virus.

This study will create awareness among people about the hidden power of discourse as our political leaders have motifs behind the discourse of good will and they try to take advantage of the current scenario and criticize each other so that they can remain in good books of public. They are constructing their positive image by pointing out government as it is not working up to the expectations of public. This is power of discourse. The purpose behind using this discourse is to evoke the sense of having real images of political league and their hidden motifs which are not for the public rather for themselves. Language is a very important tool as it can construct or deconstruct images of the people. These political leaders use this tool skillfully to manipulate the interest of public.

It is evident from the paper that political league did not provide solution rather manipulated public's attention to the opposing parties. Reaching out to solution can never be considered as the responsibility of an individual rather all political leaders and public are required to work in collaboration to come up with solution which can be taken as life- saving remedy rather than being materialistic and self-righteous.

To encapsulate, our society as a whole can easily be influenced to find the real being in its true sense of politics. This idea is in consent with Gee's statement (2001)that language is inherently political in a deep sense. Social goods are the stuff of politics. Politics is not just about contending political parties. In a deeper level, it is about how to distribute social goods in a society: who gets what in terms of money, status, power and acceptance on a variety of different terms, all social goods so when language is used, social goods and its distribution is always at stake that's why it is always political in its deep sense (Gee, 2001). All political parties are working for social goods which are anything some people in a society want and value by putting distribution of social goods at risk. Their hidden purpose can be coined from the depth of words they use in statements on different political forums.

\section{REFERENCES}

A Review on Critical discourse Analysis by Ke Liu, Fang, Guo

Covid-19 Pandemic and home online learning system; Does it affect the quality of school learning ( MamanSuryaman, cahyono, Bustani, Julina,, Sys Rev Pharm 2020;11(8):524-530)

Covid-19 Pandemic and home online learning system; Does it affect the quality of school learning (MamanSuryaman, cahyono, Bustani, Julina, Sys Rev Pharm 2020;11(8):524-530)

Critical discourse analysis in political communication research: a case study of right-wing populist discourse in Australia (Kurt Sengul, published online Nov 25, 2019)

Critical discourse analysis in political communication research: a case study of right-wing populist discourse in Australia (Kurt Sengul, published online Nov 25, 2019)

Critical Discourse Analysis: Current approaches and the advent of Mult-modality (Damien OKado-Gough, Doshisha University, August, 2017)

Crystal, D \& Robins. (2020). Language: Additional information.The Editors of Encyclopedia Britannica; University of London. Author of general Linguistics

Dijk, T.A. (2000) Political discourse ideology. Paper for Jornadasdel.

Discourse analysis /A step-by-step guide with examples (Published on August 23,2019 by Amy Luo. Revised on June 19,2020

Discourse Analysis of Journal Article by Harry Zheng,(Aug 13,2017)

Fairclough, I \& Norman Fairclough, Taylor. (2012). Political discourse Analysis: A method for advancestudents, Routledge, Taylor \& Francis group, London and New York, Milton park, Abingdon, Oxon OX14RN

Fairclough, N (1995b). Critical Discourse Analysis. London,:Longman

Fairclough, N , Kress, G.(1993): Critical Discourse Analysis

Fairclough, N(1989) Language and 
power.London:Longman

Fairclough, N(1992b)Critical language awareness. London:Longman

Fairclough, N, Wodak, R. (1997):'Critical Discourse Analysis', In: Introduction to Discourse Analysis., Van Dijk, T.A. (ed), London,258-284.

Fairclough, N. (1989) Language and power.London:Longman

Fairclough, N. (1995b). Critical Discourse Analysis. London:Longman

Fairclough,N(1995a). Media discourse. London:Edward Arnold

Fairclough,N. (1992b)Critical language awareness. London:Longman

Fairclough,N. (1995a). Media discourse. London:Edward Arnold

Hassan, A. (2018). Language, media and ideology: Critical discourse analysis of Pakistani News Bulletin Headlines and its impact on viewers.

https;//www.fb.com/arynewsasia

Introduction to Discourse by James Paul Jee

Janks, H. (1997). Critical Discourse Analysis as a Research Tool.University of the Witwatersrand, Johannesburg, South Africa

Janks, H. (1997). Critical Discourse Analysis as a Research Tool.University of the Witwatersrand.

Key terms in Discourse Analysis

Language, media and ideology: Critical discourse analysis of Pakistani News Bulletin Headlines and its impact on viewers (First published in September 1,2018 by Aaminah Hassan)

Lowenhal, P. R., Borup, West \&Archabault. (2020). Thinking Beyond Zoom: Using Asynchronous video to maintain connection and engagement during the covid-19 Pandemic, JI.of Teacher Education, USA.

Luo, A. (2019). Discourse analysis /A step-by-step guide with examples.

Martin, L.R. (2009).New Developments in Discourse Analysis: Discourse as social practice ,FoliaLinguistica/Volume35:Issue 1-2.

New Developments in Discourse Analysis: Discourse as social practice (Luisa Martin Rojo)

New Developments in Discourse Analysis: Discourse as social practice (Luisa Martin Rojo)

Okado-Gough, D. (2017). Critical Discourse Analysis: Current approaches and the advent of Mult- modality, Doshisha University, Kyoto, Japan.

Political discourse Analysis: A method for advance students (preview on textbook by IsabelaFairclough and Norman Fairclough(Taylor and francis Group, London and Newyork, published 2012 by Routledge 2 park square, ,Milton park, Abingdon, Oxon OX14RN

Political discourse Analysis: A method for advance students(preview on textbook by IsabelaFairclough and Norman Fairclough(Taylor and francis Group, London and Newyork, published 2012 by Routledge 2 park square, ,Milton park, Abingdon, Oxon 0X14

Sengul, K. (2019). Critical discourse analysis in political communication research: A case study of rightwing populist discourse, published online, Australia.

Smith,F.(1971).Understanding reading: A Psycholinguistic Analysis of Reading and Learning to read. Newyork: Holt, Rineheart and Winston.

Smith,F.(1971).Understanding reading: A Psycholinguistic Analysis of Reading and Learning to read.Newyork: Holt, Rineheart and Winston.

Stalpers, J. (1988). The Maturity of Discourse Analysis, vol.17, No. 1 ,pp.87-97 pages(11 pages) Published by Cambridge University press.

Suryaman, M, Cahyono, Bustani\&Julina. (2020). Covid-19 Pandemic and home online learning system; Does it affect the quality of school learning, Sys Rev Pharm 2020;11(8):524-530)

The Maturity of Discourse Analysis(Review Article by Judith stalpers, vol.17, No. 1(March,1988), pp.8797 pages (11 pages) Published by Cambridge University press.

Thinking Beyond Zoom: Using Asynchronous video to maintain connection and engagement during the covid-19 Pandemic(Patrick R. Lowenhal, USA, Borup, USA, West, USA, Archabault, USA)

Van Dijk, T.A (2000) Political discourse ideology. Paper for Jornadasdel.

Wodak, R. (2002). Aspects of Critical Discourse Analysis.ZfAL, Vol. 36, (Pp. 5-31).

Wodak, R. (2002). Aspects of Critical Discourse Analysis.ZfAL,Vol. 36, (Pp. 5-31).

Zheng, H. (2017). Discourse Analysis of Journal Article 
Publisher's note: EScience Press remains neutral with regard to jurisdictional claims in published maps and institutional affiliations. (c) (i) use, sharing, adaptation, distribution and reproduction in any medium or format, as long as you give appropriate credit to the original author(s) and the source, provide a link to the Creative Commons license and indicate if changes were made. The images or other thirdparty material in this article are included in the article's Creative Commons license, unless indicated otherwise in a credit line to the material. If material is not included in the article's Creative Commons license and your intended use is not permitted by statutory regulation or exceeds the permitted use, you will need to obtain permission directly from the copyright holder. To view a copy of this license, visithttp://creativecommons.org/licenses/by/4.0/.

(C) The Author(s) 2020. 